\title{
RELACJE PRZEDSIĘBIORSTW Z OTOCZENIEM NA WSI
}

\begin{abstract}
Abstrakt. Celem artykułu jest prezentacja opinii przedsiębiorców na temat ich relacji z przedstawicielami władzy lokalnej oraz społeczności gminnej. Rozważania oparto na wynikach jakościowych badań terenowych przeprowadzonych w 2016 roku techniką indywidualnych wywiadów pogłębionych z siedmioma przedstawicielami firm działających na obszarach wiejskich. Analizy, osadzone w koncepcji społecznej odpowiedzialności biznesu, prowadzą do wniosków, iż w relacjach biznesu z władzami gminy (podobnie jak z organizacjami pozarządowymi i lokalną społecznością) dominuje tzw. dyskrecjonalna filantropia i reaktywne zaangażowanie. Wynikały one głównie z nacisku społecznego, nie zaś z potrzeb przedsiębiorców. Przedsiębiorcy odwoływali się do poczucia odpowiedzialności społecznej wobec wspólnoty gminnej w zakresie ekonomicznym, prawnym i filantropijnym. Brakowało zaś argumentów o charakterze etycznym.
\end{abstract}

Słowa kluczowe: społeczna odpowiedzialność biznesu, przedsiębiorstwa na wsi, relacje z otoczeniem, obszary wiejskie.

\section{Wprowadzenie}

Od momentu zmiany systemu gospodarki w Polsce na rynkowy i zdecentralizowany, w literaturze przedmiotu nastąpił lawinowy wzrost publikacji dotyczących rozwoju gospodarczego wsi i aktywizacji jej mieszkańców na rzecz lokalnej przedsiębiorczości (np. Kłodziński 1998; Os trow ski 2000; Kłodziński, Dzun 2003; Otłowska, Buks, Chmieliński 2006; Kłodziński 2010; Gabińska 2012; Kłodziński 2014; Bański 2015). Opracowania odnosiły się zarówno do barier rozwoju przedsiębiorczości, jak i do mechanizmów jego stymulowania. Uważano bowiem, że przyrost liczby przedsiębiorstw jest jednym ze wskaźników rozwoju i im jest on wyższy w danym układzie lokalnym, tym lepiej ten region jest rozwinięty. Podstawową korzyścią płynącą ze wzrostu liczby podmiotów gospodarczych (na wsi głównie pozarolniczych) był wzrost liczby miejsc pracy, a także zwiększone wpływy z podatków do lokalnego budżetu. Współcześnie, tj. po upływie ok. 25 lat, można stwierdzić, że działania na rzecz aktywizacji

* Katedra Gospodarki Samorządu Terytorialnego, Wydział Ekonomiczno-Socjologiczny, Uniwersytet Łódzki, ul. Rewolucji 1905 r. nr 41/43, 90-214 Łódź, e-mail: malmarks@o2.pl 
lokalnego biznesu przyniosły oczekiwane efekty (zob. Wilkin, Nurzyńska 2014; Nurzyńska, Poczta 2016). Liczba przedsiębiorstw i miejsc pracy wzrosła, a bezrobocie osiągnęło relatywnie niski poziom. Nadal jednak istnieją w Polsce obszary o słabym rozwoju, a problem aktywności przedsiębiorczej jest tam jednym z bardziej dotkliwych (Rosner, Stanny 2014).

Na rozwój przedsiębiorczości wpływa wiele czynników, zależnych zarówno od wewnętrznych uwarunkowań organizacyjno-zarządczych i finansowych, jak również od tzw. otoczenia zewnętrznego firmy. Wśród nich Iwona Nurzyńska (2011: 115) wymienia politykę władz, dostępność różnego typu zasobów, instytucji doradczych i finansowych, terenów inwestycyjnych, rozwiniętą infrastrukturę techniczną, dostawców usług i mediów, rynki lokalne i istniejący na nich popyt, a także technologie. Jednocześnie autorka podkreśla, iż ważnymi elementami tego środowiska są otwartość społeczności lokalnych na nowe pomysły i gotowość akceptowania ewentualnych niepowodzeń, obecność kultury przedsiębiorczości i tradycji zachowań przedsiębiorczych społeczności. Istnieje wiele przykładów działań podejmowanych przez lokalne władze promujących miejscowy rozwój gospodarczy (Dziemianowicz i in. 2000; Marks 2006), np. wsparcie i doradztwo przy zakładaniu działalności gospodarczej, współtworzenie lokalnych sieci, organizacja wydarzeń związanych z lokalnym rynkiem, promocja przedsiębiorczości wśród określonych grup społecznych (np. wśród młodzieży) itp. Władzom na obszarach wiejskich zaleca się rozpoznanie konkretnych wyzwań i możliwości, przed którymi stają przedsiębiorcy (np. odległość od rynków, niższa dostępność kapitału i tendencja przedsiębiorców do poszukiwania dostępu do źródeł wsparcia), i na tej podstawie opracowanie pakietów wsparcia lokalnego biznesu (por. Atterton, Affleck 2010).

Nie negując wagi pozostałych elementów otoczenia, warto zastanowić się nad współczesnym kształtem relacji zachodzących między przedsiębiorcami prowadzącymi działalność na wsi a ich najbliższym otoczeniem, tj. władzą lokalną i mieszkańcami. Relacje te mogą mieć wpływ na tworzenie tzw. „klimatu dla przedsiębiorców", ale również mogą wzmacniać poczucie społecznej odpowiedzialności i zaangażowanie przedsiębiorców w lokalne życie publiczne oraz promować nową - publiczną - rolę biznesu, utożsamianą z aktywnym obywatelstwem i świadomym kreowaniem zmian społecznych. Celem artykułu jest zatem prezentacja opinii przedsiębiorców na temat ich relacji z przedstawicielami lokalnej władzy i społecznością lokalną. Rozważania osadzone będą w koncepcji społecznej odpowiedzialności biznesu (Corporate Social Responsibility - CSR). 


\section{Społeczna odpowiedzialność biznesu}

Społeczna odpowiedzialność biznesu to koncepcja rozwijana na bazie obserwacji praktyk biznesowych w uprzemysłowionych i kapitalistycznych krajach Europy i Stanów Zjednoczonych, w Polsce od kilkunastu lat cieszy się niesłabnącym powodzeniem. Ogólnie określana jest jako poczucie obowiązku biznesu wobec społeczeństwa. Mimo że pojęcie to znane było już wcześniej, jego współczesne rozumienie zapoczątkowano w latach 50. ubiegłego stulecia (Carroll 1999). Znaczną popularność zarówno w biznesie, jak i w pracach naukowych, zyskało z końcem lat 90. XX wieku.

Howard Bowen (1953), autor pierwszej książki o doktrynie odpowiedzialności społecznej, uważał, że firmy mają wpływ zarówno na własne działania, jak i na społeczeństwo jako całość. Społeczną odpowiedzialność zdefiniował wówczas jako zobowiązania przedsiębiorców do prowadzenia takich polityk, podejmowania decyzji lub podążania takimi drogami działania, które są pożądane z punktu widzenia celów i wartości społeczeństwa.

Z perspektywy ogólnospołecznej przyjmowano więc, że korporacja jest instrumentem tworzenia bogactwa $\mathrm{i}$ jest to jej jedyna odpowiedzialność społeczna. Dlatego, w owym czasie, w relacjach między biznesem a społeczeństwem uwzględniano wyłącznie ekonomiczny aspekt. CSR postrzegany był jako strategiczne narzędzie służące osiągnięciu celów gospodarczych, a w konsekwencji tworzeniu dobrobytu i bogactwa społeczeństwa. Z perspektywy biznesowej, pierwotnie, celem działania $\mathrm{w}$ imię społecznej odpowiedzialności było nie tyle rozwiązywanie problemów w społeczeństwie, co wdrożenie mechanizmu wspomagającego działalność biznesową. CSR był zatem jednym ze środków służących przedsiębiorstwu w osiąganiu jego zysków. Zakładano, że wszelkie inwestycje w zaspokojenie społecznych potrzeb, które mogłyby spowodować wzrost dochodów lub wartości dla akcjonariuszy, powinny być dokonywane, w przeciwienstwie do tych, które wymagają od firmy jedynie ponoszenia kosztów.

Milton Friedman (1970) dostrzegł, że w praktyce doktryna odpowiedzialności społecznej bywa płaszczem dla działań uzasadnionych innymi względami, bowiem działalność społeczna, z perspektywy długookresowej, może leżeć $\mathrm{w}$ interesie dużego przedsiębiorstwa. Przykładowo, główny pracodawca w małej społeczności może mieć długoterminowy interes w przeznaczaniu części swoich zasobów na tworzenie różnego typu udogodnień dla społeczności, wspierając $\mathrm{w}$ ten sposób zarządzanie nią. $\mathrm{Z}$ jednej strony ułatwia to przyciąganie nowych, pożądanych pracowników do jego firmy, z drugiej zaś zabezpiecza przed ewentualnymi stratami z powodu kradzieży lub sabotażu ze strony społeczności. Korzyścią dla biznesu jest również oficjalne przekazywanie darowizn na cele społeczne, o kwoty te bowiem można pomniejszyć zobowiązania podatkowe. Filantropia poprawia także pozycję konkurencyjną firmy (Porter 1992). Odpowiedni poziom inwestowania $\mathrm{w}$ działalność społeczną jest zatem akceptowany przez 
przedsiębiorstwa ze względu na oczekiwane w przyszłości zyski (McWilliams, Siegel 2001). Stwierdzenie to znajduje także odzwierciedlenie w licznych badaniach wskazujących na dodatnią korelację między odpowiedzialnością społeczną a wynikami finansowymi korporacji (Griffin, Mahon 1997; Waddock, Graves 1997). Opisane wyżej instrumentalne podejście ma zatem długą tradycję i wciąż cieszy się akceptacją środowisk biznesowych. Jak zauważył Windsor, „motyw przewodni kreacji bogactwa stopniowo dominuje w managementowej koncepcji odpowiedzialności" (2001: 226).

Istotną rolę $\mathrm{w}$ rozwijaniu podejścia do CSR odegrały ruchy społeczne (na rzecz praw obywatelskich, konsumenckich, kobiet czy ruchy ekologiczne). Wpłynęły one bowiem na zmianę środowiska społecznego i wywarły presję (np. poprzez naciski ze strony aktywistów) na postrzeganie przez przedsiębiorców oczekiwań otoczenia i znajdowanie sposobu ich zaspokajania (por. Carroll, Shabana 2010). Przyczyniło się to do dalszego rozwijania (w latach siedemdziesiątych i osiemdziesiątych) definicji CSR. Pojęcie to rozumiano wówczas jako coś więcej niż tylko działanie wspierające przedsiębiorstwa w osiąganiu przez nie celów biznesowych, a mianowicie postrzegano je jako działanie kierujące się etyką, a nawet społeczny obowiązek, zaczęto także uwzględniać w nim zaangażowanie szeroko rozumianych interesariuszy (por. Carrol 1991).

Ważny wymiar dyskusji na temat CSR dotyczy kategorii etycznych. Odpowiedzialność etyczna wskazuje te działania i praktyki, które są oczekiwane lub zabronione przez społeczeństwo (społeczność), mimo że nie są skodyfikowane prawem. Są one jednak ucieleśnieniem norm i oczekiwań, odzwierciedlających troskę o to, co konsumenci, pracownicy, akcjonariusze czy społeczność uznają za sprawiedliwe, uczciwe i szanujące prawa moralne zainteresowanych stron. Schwartz i Carroll (2003) opisali trzy standardy, które powinny spełniać przedsiębiorstwa mające się za etyczne. Pierwszym z nich jest standard konwencji odwołujący się do spełniania formalnych (choć nie wyłącznie) kodeksów postępowania, niezbędnych do funkcjonowania biznesu. Drugi, tzw. standard konsekwencji odnosi się do tego, czy działanie przyczynia się do promowania dobra społeczeństwa. Ostatni, trzeci standard deontologiczny dotyczy obowiązków i zobowiązań firmy w zakresie zachowania wiarygodności (uczciwości, niezawodności, lojalności), odpowiedzialności, opiekuńczości (np. unikania niepotrzebnych szkód) i obywatelstwa (np. pomagania społeczności, ochrony środowiska).

Inną perspektywę analiz przyjął Keith Davis (1960), zwracając uwagę na konieczność włączania idei społecznej odpowiedzialności w proces zarządczy przedsiębiorstwa, bez niej bowiem utraci ono władzę społeczną (social power) i wpływ na otoczenie. Autor podkreśla, że biznesmeni są ludźmi inteligentnymi, liderami, kompetentnymi twórcami i innowatorami, a to, co mówią i robią, powinno mieć wpływ na politykę (np. zatrudnienia, przedsiębiorczości, edukacji itp.). Zakłada, że biznes jest instytucją społeczną i posiadając władzę, może odpowiedzialnie (także w interesie społeczeństwa) wpływać na zmiany i postęp. 
Biznesmeni staną się wówczas, jak sarkastycznie wskazuje Davis, menadżerami przyszłości, a nie żałosnymi ofiarami restrykcyjnego otoczenia (Davis 1960: 74). Cytowany autor był zatem jednym z pierwszych, którzy odkryli rolę władczą, jaką biznes posiada w społeczeństwie, wprowadzając w ten sposób nowy element debaty na temat CSR.

Współczesna dyskusja na temat szerszego wpływu biznesu na społeczeństwo toczy się w ramach tzw. korporacyjnego obywatelstwa (corporate citizenship). Idea traktowania firmy jako obywatela nie jest nowa (Davis 1973), termin ten został wprowadzony do relacji biznesowych i społecznych w latach 80. (Altman, Vidaver-Cohen 2000), a dziś cieszy się szczególnym zainteresowaniem (zob. np. Crane 2008; Carrol 2015). Korporacyjne obywatelstwo oznacza zarządzanie firmą w zakresie jej wpływów i relacji z resztą społeczeństwa. Początkowo polegało ono na zgodnym z obowiązującym prawem i normami społecznymi prowadzeniu biznesu, płaceniu podatków i byciu dobrym sąsiadem, czego należy spodziewać się od zwykłego obywatela (Marsden 2000). Współcześnie oczekuje się także, zwłaszcza od dużych międzynarodowych korporacji, większego (niż uznaniowa filantropia) zaangażowania w rozwiązywanie problemów społecznych czy ekologicznych. Ideę korporacyjnego obywatelstwa można sprowadzić do przestrzegania dwóch głównych zasad (McInto sh i in. 2003). Po pierwsze, do zrozumienia i akceptacji przez firmę, że jest ona zarówno podmiotem prywatnym, jak i publicznym. Powstała bowiem jako twór społeczeństwa i czerpie z niego legitymację do swoich działań. Potrzebuje więc wyartykułowania i wspierania swojej nowej roli. Po drugie, korporacyjne obywatelstwo oznacza dostrzeżenie i zrozumienie przez firmę zarówno jej wpływu na środowisko i społeczeństwo, jak również obowiązków regulacyjnych (sprawozdawczość finansowa, bezpieczeństwo zdrowotne, prawo pracy) czy społecznych (np. pozyskanie zgody społeczności na działanie). Zatem, zarówno od firm-obywateli, jak i społeczeństwa oczekuje się uznania szeregu obowiązków (etycznych, prawnych, ekonomicznych, filantropijnych) i akceptacji publicznej (obywatelskiej) roli prywatnych podmiotów gospodarczych. Ponadto, odwołując się do norm etycznych, zachowanie firmy powinno być zgodne $\mathrm{z}$ obowiązującymi w danym społeczeństwie (społeczności) kodeksami (także nieformalnymi).

Chris Marsden (2000) opisał cztery typy działań podejmowanych przez duże firmy charakteryzujące współczesne korporacyjne obywatelstwo. Po pierwsze jest to odchodzenie od tzw. reaktywnych grantów do strategicznych inwestycji społecznych. Zwykle są to działania realizowane w długim okresie i nawiązują do profilu działania firmy. Po drugie aktywność skoncentrowana jest na zarządzaniu relacjami z interesariuszami, sojusznikami, sieciami. Działania te mają na celu wzrost znaczenia tych relacji dla osiągnięcia trwałego sukcesu biznesowego, opierają się na realizacji strategicznych inwestycji społecznych. Po trzecie część działań polega na współtworzeniu polityki publicznej (krajowej lub międzynarodowej), poprzez współpracę z rządem lub organizacjami pozarządowymi. Po 
czwarte, odzwierciedlając zainteresowanie nowymi sposobami mierzenia wyników pracy i oddziaływania na otoczenie, prowadzone są nowoczesne pomiary, audyty i sprawozdawczość. Mają one na celu nie tylko monitorowanie bieżącej działalności, ale również informowanie otoczenia o jej społeczno-środowiskowych skutkach.

Podsumowując, literatura i życie społeczne dostarczają wielu spojrzeń i poglądów na oczekiwania wobec przedsiębiorstw, począwszy od tradycyjnego (choć w wielu przypadkach wciąż aktualnego), u podstaw którego leży założenie, że firma ponosi odpowiedzialność wyłącznie wobec jej właścicieli, aż do nowoczesnego (wymagającego większej społecznej wrażliwości), przyjmującego, że przedsiębiorstwo ma prawa, ale również obowiązki, podobnie jak odpowiedzialny obywatel.

\section{Relacje przedsiębiorców z otoczeniem - wyniki badań własnych}

\subsection{Zalożenia metodologiczne}

Przywołany we wstępie cel artykułu zostanie osiągnięty poprzez dokonanie charakterystyki relacji zachodzących między przedsiębiorcami a lokalnymi władzami i społecznością. Przedmiot zainteresowania stanowią również cechy relacji odnoszące się do społecznej odpowiedzialności. Rozważania oparte zostały na wynikach badań terenowych realizowanych w latach 2015-2018, prowadzonych w ramach projektu badawczego finansowanego przez Narodowe Centrum Nauki pt. „Modele zarządzania i ich uwarunkowania w gminach wiejskich” (UMO-2014/14/E/HS6/00398).

W przypadku doboru gmin do badania kierowano się zróżnicowaniem ich społeczno-ekonomicznego rozwoju. Spośród 134 gmin wiejskich województwa łódzkiego wylosowano po dwie jednostki o wysokim (Zgierz, Nieborów), średnim (Widawa, Godzianów) i niskim (Wielgomłyny i Strzelce Wielkie) poziomie tego wskaźnika. Następnie w każdej z nich przeprowadzono co najmniej jeden wywiad z osobą prowadzącą działalność gospodarczą. Kryterium doboru respondentów było wskazanie przez innych respondentów (władze lokalne, organizacje pozarządowe, lokalnych działaczy) danego przedsiębiorcy jako odgrywającego znaczącą rolę w lokalnym życiu publicznym.

W niniejszym artykule analizie poddano zatem treść siedmiu indywidualnych wywiadów pogłębionych przeprowadzonych (w 2016 r.) z przedsiębiorcami. Wszyscy biznesmeni prowadzili działalność powyżej 20 lat. Większość $\mathrm{z}$ nich było silnie zakorzenionych $\mathrm{w}$ środowisku lokalnym (od urodzenia mieszkali w miejscowości, w której prowadzili biznes). Najkrótszy okres zamieszkiwania to 23 lata. W badaniu uczestniczyli właściciele (lub współwłaściciele) zarówno dużych firm, zatrudniających nawet do 500 osób, jak i dwóch małych, 
jednoosobowych. Większe przedsiębiorstwa zajmowały się sprzedażą maszyn rolniczych i komunalnych, przetwórstwem mięsnym. Mniejsze zaś pośrednictwem handlowym i prowadzeniem domu bankietowego, pracami budowlanymi, gospodarstwem rolnym i prowadzeniem farmy wiatrowej, a także recyklingiem samochodowym i punktem małej gastronomii. Wielkość firmy i typ prowadzonego biznesu nie różnicowały poziomu społeczno-ekonomicznego rozwoju gminy.

\subsection{Relacje $z$ wladzami gminy}

Rozmówcy zdawali sobie sprawę zarówno z konieczności, jak i zalet współpracy z samorządem: „Jak jest prywatny przedsiębiorca, to też musi być współpraca: biznes i samorząd”. Jednocześnie respondent zwracał uwagę, że każdy biznesmen planujący rozwinąc działalność gospodarczą na danym terenie omawia tę sprawę najpierw z wójtem, jemu powierza tajemnicę biznesową: „,każdy biznesmen czy inwestor przychodzi do wójtów. Co oni wiedzą i jakie mają pomysły to dzielą się z tymi co muszą". Ponadto wójt może stanowić także cenne źródło wiedzy dla przedsiębiorcy: „Wójt był dla mnie nie tylko gospodarzem gminy, ale zasięgałem też od niego informację, aby być mądrzejszym, zabierając głos wśród wójtów w powiecie". Inny zauważył, odwołując się do znanych mu przykładów, że przedsiębiorcy dzięki współpracy mogą mieć wpływ na gminę: „przedsiębiorcy mają wpływ na gminę i to jest w ramach współpracy". O relacjach z władzą przedsiębiorcy wypowiadali się często w duchu tzw. układów: „Są to jakieś układy bardzo poprawne z jednej, drugiej i trzeciej strony".

Jedną z najczęściej deklarowanych form współpracy jest bezpośrednia pomoc przedsiębiorcy w realizacji społeczno-kulturowych inicjatyw urzędu gminy lub lokalnych władz. Polegała ona na dofinansowaniu lub sponsorowaniu festynów, promocji gminy, zakupie strojów ludowych i uczestnictwie w dożynkach. Przedsiębiorcy z reguły mieli poczucie obowiązku wspierania tych przedsięwzięć: „Niestety samorząd trzeba wspierać w różny sposób. Tutaj gmina dała środki na to, ale tak jak ja i wielu innych włożyło swoje cegiełki”. Ponadto właściciele firm pomagali pozafinansowo, np. użyczając sprzęt czy przeznaczając produkty własnej wytwórczości na nagrody lub do spożycia przez uczestników zabawy (darowizny rzeczowe): „Dajemy za darmo estradę, prąd, media wszystkie i samorząd biesiaduje tutaj elegancko. Jesteśmy otwarci. Jak są jakieś imprezy, to ich wspomagamy owocami masarni". W jednym przypadku pomoc miała charakter doradczy: „Nawet jak kupowali traktor przez ten przetarg, to staraliśmy się znaleźć maszynę w tym przewidzianym budżecie, ale z lepszym wyposażeniem”. Zaangażowanie polegało również na wykonywaniu pewnych prac na rzecz gminy. Przykładowo, jeden z respondentów angażował swoich pracowników w wykonanie prac porządkowych, inny w odnowę, renowację ważnych dla gminy obiektów, jak pomniki, strażnice itp.: „Gmina zapewniła materiały, a moja firma zrobiła tam remont nieodpłatnie”, kolejny w naprawę sprzętu: „Pomagamy im. Jak przyjadą 
i coś im się popsuje w tych sprzętach, to naprawimy. Zawsze są szybko obsłużeni, bo są blisko. Zawsze się odłoży inną pracę i się im pomoże”.

W wypowiedziach przedsiębiorców często powtarzał się motyw wiodącej, inicjatywnej roli wójta, znajdującej oparcie w dobrej znajomości z respondentami: „Wójt przychodzi i mówi 'daj trochę'; Wójt mówi tak: będziemy robili obchody dni [naszej wsi - przyp. M.M.-K.]. Proszę bardzo, użyczamy”. Impuls do działania pomocowego nie płynie zatem ze strony biznesmenów: „gmina się kontaktuje, od nas nie ma na to nikt czasu".

Zaangażowanie przedsiębiorcy niesie również ze sobą ryzyko przypisania złych intencji, na co wskazał jeden z respondentów: „Traktują, że jak sponsoruję, to chcę przekupić kogoś, będę startował w wyborach. Rozmywa się to wszystko. Takie jest podejście władzy".

Współpraca z urzędem była różnie oceniana, bieżąca na ogół pozytywnie: „U nas jest tak, że wójt chce współpracować. Jak rozmawiam z innymi kolegami, którzy prowadzą firmy, to raczej nie mają problemów, żeby tam gmina stwarzała", zaś długookresowe planowanie i wizja rozwoju - negatywnie: „Jeśli chodzi o odważne decyzje $i$ inwestycje w dłuższym czasie, to mam niedosyt. Nie powinno się patrzeć na to co jest teraz, tylko na 5, 10 lat do przodu. Aby następne pokolenie miało tą infrastrukturę zbudowaną". Dobra ocena działalności gminy wynikała także z porównania stylu pracy wójta do biznesmena: „patrząc z perspektywy samego siebie jako przedsiębiorcy, to który przedsiębiorca nie bierze kredytu, żeby się rozwijać? Jak się ma wykonać jakąś dużą usługę, to trzeba się podeprzeć kredytem".

Przyczyny braku działań strategicznych i reorganizacji na rzecz nowych metod i narzędzi rozwoju tkwią, zdaniem respondenta, w mentalności urzędników, którzy nie chcą podejmować nowych wyzwań i zwiększać zakresu własnych obowiązków i obciążeń zawodowych: „to jest sposób myślenia poszczególnych osób w gminie, pracowników gminy, którzy nie do końca chcą sobie przysparzać więcej pracy. [...] Specjalne komórki do pozyskiwania środków unijnych. U nas tego nie ma, mimo że to jest największa gmina w powiecie". Respondent zwracał także uwagę na zmiany w planach zagospodarowania, które bardzo utrudniają mu rozwój. Wówczas gmina postrzegana jest jako „hamulcowy” rozwoju. Na niekorzystny obraz zarządzania gminą wpływa nie tylko krótkowzroczność i brak pomysłu władz, ale również podejrzenie przywiązywania większej wagi do zabezpieczenia prywatnych interesów: „Nie idziemy z duchem czasu. Jest krnąbrność władzy, która mnie przeraża. Traktują gminę jak swoją rzecz. Inaczej to widziałem".

Niektórzy przedsiębiorcy byli zdania, że wręcz powinni być partnerami dla władz w zarządzaniu gminą, bez konieczności włączania pośredników (np. powiatu czy instytucji zewnętrznych). Zarówno ze względu na korzyści, jakie czerpie z nich cała społeczność, jak i z uwagi na więzi między przedsiębiorcami a pracownikami gminy, najlepiej znającymi jej specyfikę. Inny biznesmen, szerzej patrząc na tę problematykę zauważył, że partnerstwo jest możliwe ,jeśli 
samorząd i przedsiębiorca widzą wspólny cel. Jeżeli to przyniesie korzyści nie tylko przedsiębiorcy, ale i samorządowi”. Ważne jest również poczucie jednakowego traktowania wszystkich biznesmenów, a także traktowanie w sposób mniej instrumentalny, bardziej podmiotowy: „Przedsiębiorcę gmina postrzega jako podatnika i źródło pieniędzy. Więcej nic. [...] Podatki płacę, tyle ile się należy, ale jak wójt na różnych spotkaniach mówi, że płacę za małe, to chyba coś jest nie tak. Ja za rok 200000 zł podatków płacę. Władza chora na pieniądze".

Wśród uczestników badania znalazł się także przedsiębiorca, którego zdaniem biznes nie powinien być partnerem w zarządzaniu gminą. Wówczas rola firmy w gminie ogranicza się do płacenia podatków i społecznego wspierania.

Ważny wątek $\mathrm{w}$ relacjach $\mathrm{z}$ otoczeniem dotyczy uzależnienia lokalnych przedsiębiorców od prac zlecanych przez gminę. Dotyczy to najczęściej mniejszych firm, które często startują w przetargach i je wygrywają, jednocześnie swoją działalność opierają głównie na tej współpracy. Przedsiębiorca, który ma poczucie niezależności od lokalnych zleceń i władz, śmiało wypowiada się krytycznie o mankamentach gminy: „Usług nie świadczę. Wójt mnie nie zatrudnia. [...] mówię głośno o rzeczach, które mi się nie podobają [...]. Zgłaszam i nie jest to mile widziane. [...] Każdy jest wygodny i nie chce głośno powiedzieć, żeby się narażać innym [...]. Ja jestem takim nietypowym przedsiębiorcą, bo nie muszę świadczyć usług dla gminy. Ja mogę otwarcie wyrażać swoje opinie". Inny biznesmen, deklarujący duże poczucie wpływu na sprawy lokalne i bardzo szerokie nieformalne kontakty z głównymi aktorami sceny lokalnej, unika konfliktów i przyjmuje inną strategię: ,ja nie jestem osobą stawiającą jednoznacznie tematy". W ten sposób nie przysparza sobie wrogów i osiąga swoje cele.

\subsection{Relacje ze społecznością}

Partnerstwo i współpraca między biznesem a władzami gminy (w znaczeniu strategicznym, długookresowym) oznacza, że potencjalnie społeczność lokalna i rozwiązywanie jej problemów mogą stać się wspólnie podzielanym celem. Rozważania te stają się interesujące w kontekście poczucia wśród lokalnych przedsiębiorców tzw. społecznej odpowiedzialności.

Zdaniem badanych biznesmenów, CSR oznacza, że ,przedsiębiorca zdaje sobie sprawę jak jego działania na danym terenie wpływają na daną społeczność lokalną, czy wnosi coś do tego społeczeństwa czy nie?” oraz „bardzo dobry ruch, który pomaga $\mathrm{w}$ różnych takich rzeczach [...] można pomóc różnym instytucjom, stowarzyszeniom w ich planach rozwojowych czy pomóc w materiałach". Tak precyzyjnie sformułowane definicje podało zaledwie dwóch badanych. Jeden z respondentów nie znał terminu CSR, lecz opowiadając o własnych działaniach na rzecz społeczności, sformułował tezy wprost idealnie odpowiadające jego współczesnym założeniom: „Przedsiębiorca powinien być otwarty nie tylko na pracowników, ale na środowisko, w którym żyje. Współpracować z tym 
środowiskiem. Wspierać samorząd i odwrotnie również. Samorząd powinien wspierać przedsiębiorców i wszystkie organizacje. Tak jak my to czynimy i z tego tytułu mamy wdzięczność, powiedzmy. [...] Przedsiębiorca musi być zintegrowany ze środowiskiem, gdzie żyje i pracuje. Zintegrowany na maksa".

Część rozmówców, zwłaszcza tych, którzy nie deklarowali zainteresowania sprawami lokalnymi i współpracą z gminą, nie potrafiła odnieść się do sformułowania społeczna odpowiedzialność biznesu: „Społeczna? Nie wiem. Raczej nie mam [poczucia obowiązku - przyp. M.M.-K.]”.

Ze względu na jedność miejsca pochodzenia przedsiębiorcy i prowadzenia firmy odpowiedzialność za oddziaływanie na otoczenie nosi znamiona wioskowego patriotyzmu: „Bo ja wiem, może po części na terenie mojej wsi. Bo na terenie całej gminy to raczej nie". Gmina jako całość nie istnieje w percepcji respondentów. Poczucie odpowiedzialności odnosi się raczej do (obowiązku, solidarności) odruchu pomocy w sytuacjach nagłych, kryzysowych (interwencji), niż rekompensowania społeczności/sąsiedztwu skutków negatywnego wpływu działalności czy zapobiegania im.

Przedsiębiorcy angażowali się natomiast chętnie w niesienie bezpośredniej pomocy lokalnym organizacjom (straż, kluby sportowe, zespoły artystyczne, koła gospodyń wiejskich). Przyjmowała ona podobne formy do pomocy urzędowi. Przede wszystkim miała charakter finansowego wsparcia (sponsoringu): „Każda z naszych firm wspiera społeczność gminy [poprzez sponsorowanie - przyp. M.M.-K.], [...] było 20-lecie KGW w tą sobotę, finansowo to wsparliśmy. Klub sportowy Orzeł przez syna był wspierany. Jednostki OSP również wspieramy finansowo. Społecznie działamy w ten sposób, że mamy drużynę sportową i ją wspieramy. Tata jest tam prezesem od zawsze. Założył ten klub ze 30 lat temu. Wspomaga finansowo i mentalnie". Pomoc przybierała też formę doradztwa organizacjom: „Moja osoba mogła być doradczą siłą, wspomagającą ekonomicznie, w działaniach bojowych niestety na to nie mogłem sobie pozwolić". Ponadto przedsiębiorca użyczał sprzęt czy teren do ćwiczeń bojowych lokalnej straży pożarnej: „Dostają do dyspozycji samochody i na nich ćwiczą jak się dobrać, aby człowieka z samochodu wyciągnąc i jak najmniej go uszkodzić".

Zaangażowanie dwóch przedsiębiorców dotyczyło także tzw. „kościelnych spraw na terenie gminy". Polegało ono na przygotowaniu szopki bożonarodzeniowej czy wypożyczeniu samochodów na pielgrzymkę. Współpraca z Kościołem, podobnie jak z gminą, opiera się na prywatnych relacjach i wspólnocie przekonań: „My jesteśmy akurat osobami wierzącymi, mamy tutaj kościół i zaprzyjaźnionego księdza, też tutaj pomagamy zawsze coś zrobić. Ta inicjatywa kościelna, inicjatywa piłki nożnej, to działa na społeczeństwo".

Impuls do zaangażowania przedsiębiorców w działalność pomocową płynął ze strony przedstawicieli organizacji, znacznie rzadziej zaś ze strony przedsiębiorców: „Straże, to od czasu do czasu jak przyjdą to pomożemy; jeśli chodzi o takie mniejsze rzeczy ze strażą czy jak z przedszkola ktoś przyjdzie, to jak poproszą". 
Przedsiębiorcy wspierali te obszary działalności społecznej, które wydawały się im ważne: „To są takie inicjatywy które uważamy, że powinniśmy robić”. Kryterium wyboru podmiotów, którym się pomaga, stanowiła także osobista znajomość (np. z wójtem, księdzem) i zbieżność z wartościami i ideami wspólnie z przedstawicielami tych podmiotów podzielanymi: „Na niektóre rzeczy, które są dla nas priorytetowe, to muszą się znaleźć fundusze. Jak ktoś przyjdzie do nas i uzasadni właściwie, że jest fajna inicjatywa i należy temu pomóc, to wtedy jest to rozpatrywane. Niektóre miejsca my wybieramy, ale też nie myśli się o wszystkim".

Natężenie i forma zaangażowania przedsiębiorstwa w działalność pomocową zależy również od wielkości i kondycji ekonomicznej firmy: „firma, którą zarządzałem, była pod względem ekonomicznym najlepiej usytuowana $\mathrm{w}$ tym środowisku i pracownicy mieli największe wynagrodzenia [...]. Z tego powodu mogłem włączyć ją w tą aktywność społeczną mając zapewnienie, że zakład funkcjonuje prawidłowo".

Przedsiębiorcy rzadko zauważali jednak problem negatywnego oddziaływania własnej firmy na otoczenie, mimo że prowadzili najczęściej biznes wymagający przed jego uruchomieniem przygotowania e-raportu oddziaływania na środowisko (hodowla i ubojnia trzody chlewnej, farma wiatrowa itp.). Dzieje się tak nawet wtedy, gdy ich działalności towarzyszą protesty: „nie spotkałem się, żeby jakieś protesty, czy żeby ktoś pisał pismo do gminy, że jest to uciążliwe. Raczej w gminie, jak rozmawiałem z przedsiębiorcami, to nikomu się nic takiego nie przytrafiło. Jeżeli chodzi o firmę, to nic mi nie wiadomo, że ktoś narzeka, bo w sumie to nikt tu nie mieszka”. Inny rozmówca zauważa: „To są trzy firmy po sąsiedzku, gospodarze. Oni tam byli od zawsze. Oni nie protestowali”, dając wyraźnie do zrozumienia, że protestują ludzie napływowi lub spoza danej wsi, w której znajduje się zakład. Argumentacja, która pozwalała przedsiębiorcom nie zwracać uwagi na uciążliwości wobec otoczenia, odwoływała się do zgodności z obowiązującym prawem i pierwszeństwa w zasiedzeniu danego terenu: „Wszystko, co jest budowane $\mathrm{w}$ tym środowisku, musi mieć podstawy prawne uzgodnione ze środowiskiem i otoczeniem, które otacza zakład. Tak to było spełnione [...]. Najpierw powstał zakład. a potem osiedle. Tu ludzie godzili się na to co ich otacza".

Wyraźnie rysował się konflikt interesów, wynikający z wizji (zrównoważonego) rozwoju gminy, między przedsiębiorcą a protestującymi mieszkańcami: „Mamy tutaj kilku rozrabiaków, [...] mamy takiego jednego, człowiek z wyższym wykształceniem, a pierdoła do kwadratu. W związku z tym mamy go dosyć, ale musi tutaj żyć. Mieszkaniec i już. Wiele rzeczy mu się nie podoba. Chciałby skansen zrobić tutaj, ale my jako przedsiębiorcy się nie dajemy. Ja go czasem nawet postraszyłem. Niech pan pilnuje swojej zagrody, a przedsiębiorczości nie likwiduje. Przedsiębiorczość jest dobrem dla danego środowiska. Ludzie płacą podatki, dają pracę, napędzają gospodarkę. Jeśli zrobimy skansen, to z turystyki samej nie damy rady; oni [mieszkańcy protestujący przeciw budowie centrum logistycznego i parkingu dla tirów - przyp. M.M.-K.] zablokowali strefę ekonomiczną, 
która miała powstać". Rozmówca nie wspomniał jednak ani razu o ewentualnym negatywnym oddziaływaniu własnej firmy na otoczenie. Inny z kolei miał świadomość sprzeciwów zarówno mieszkańców, jak i innych środowisk, nawet ekologów: „Wbrew temu co się mówi, to jest monitorowane”, lecz nie podzielał argumentów oponentów i nie dostrzegał potencjalnego oddziaływania przedsięwzięcia na otoczenie.

Dla zaledwie jednego przedsiębiorcy, prowadzącego firmę o lokalnym zasięgu, dobre relacje ze społecznością wydają się być gwarantem powodzenia. W społeczności widzi bowiem zarówno pracowników, potencjalnych klientów, jak również sąsiadów: „Mieszkańcy gminy u nas pracują, a jednocześnie dają nam zarobić. Jeśli samochód wycofa się z eksploatacji i przyprowadzi do nas, to my go kupimy. Tak samo jak każdy kto przyjedzie na przegląd, to jest szanowany przez nas, bo to są nasze pieniążki. W jakimś stopniu one spływają do tej społeczności”.

Olbrzymie znaczenie wydają się także mieć relacje dobrosąsiedzkie: „Doszedłem do wniosku, że otoczenie jest ważniejsze niż te gęsi. Wycofaliśmy się z tego, bo ludzie mieli rację. [...]. Ja sam chodziłem po wsi i to czułem [odór - przyp. M.M.-K.]. Ja sam tutaj mieszkam. Ja jak idę ulicą, to mają mnie pokazać i mówić nieprzyzwoite słowa? Z chłopakami ustaliliśmy, że się wycofujemy". Poza spełnieniem wymogów formalnych, uzyskanych w stosownych urzędach, ważna jest zatem akceptacja działalności przez lokalną społeczność. Wydaje się, że w małym wiejskim środowisku jest o nią łatwiej miejscowemu przedsiębiorcy ze względu na dobrą znajomość tego środowiska: „musieliśmy uzyskać pozwolenie i zgodę tej społeczności, która jest najbliżej, czy nie widzą przeszkód. Takie rozmowy prowadziliśmy. Osobiście chodziłem do sąsiadów i mówiłem, że będzie coś takiego". Jednocześnie niewyrażenie zgody na określoną działalność niesie ze sobą szereg konsekwencji dla mieszkańca, potencjalnego pracownika: „Nawet podpisy zbierali na osiedlu, a potem ludzie z tego osiedla przyszli i powiedzieli, że chcą pracować. Proszę Pani, ale Pani się podpisała!". Negatywne oddziaływanie firmy na otoczenie niesie ze sobą ryzyko konfliktów i wzajemnych animozji.

Jeden $\mathrm{z}$ respondentów podzielił się historią zakupionego przez siebie gruntu w centrum wsi, który przeznaczył na plac handlowy i darmowy parking dla mieszkańców: „Powiedziałem, że parking jest do dyspozycji mieszkańców, nie płacą złotówki. Imprezy to samo, dla naszej społeczności nie ma problemu. Wszystko za darmo. [...] Porozmawiałem z handlowcami i powiedziałem, że w czwartki od godziny 6 otwieramy tutaj i jest targowisko i przychodzą mieszkańcy i kupują co chcą [...]. Ja powiedziałem, że to ma służyć środowisku". Jest to jednak, na tle przeprowadzonych wywiadów, niestety odosobniona postawa. 


\section{Podsumowanie}

Celem artykułu była prezentacja opinii przedsiębiorców na temat ich relacji z przedstawicielami lokalnej władzy i społecznością lokalną. Zgromadzony materiał badawczy pozwolił na sformułowanie kilku konkluzji w zakresie oceny kontaktów i współpracy przedsiębiorców z władzami lokalnymi:

- po pierwsze, dominującą formą relacji jest współpraca na rzecz wzajemnej pomocy: ze strony przedsiębiorcy - finansowej (sponsoring) i pozafinansowej (rzeczowa, doradcza lub wykonywanie drobnych prac dla gminy lub urzędu), ze strony władz - doradczej i informacyjnej;

- po drugie, relacje opierają się często na osobistych, prywatnych znajomościach przedsiębiorcy z wójtem, choć nie zawsze są to kontakty towarzyskie. Respondenci nie wspominali o relacjach z radnymi (z wyjątkiem jednego, który od radnych czerpie wiedzę o tym, co dzieje się w gminie). Może to oznaczać, że wójt, a nie radni, pełni dominującą rolę w lokalnym życiu publicznym i w kontaktach $\mathrm{z}$ biznesem;

- po trzecie, zauważalna jest zależność niektórych przedsiębiorców od lokalnego systemu, np. w przypadku gdy działalność ma lokalny charakter lub w znacznym stopniu zależy od gminnych zasobów, zleceń i przetargów. Może to wpływać na relacje z władzami i wywoływać poczucie zobowiązania do angażowania się w działania gminy;

- po czwarte, ocena kontaktów przedsiębiorcy z urzędem, dotyczących bieżących spraw administracyjnych, jest znacznie wyższa niż tych dotyczących kształtowania planów strategicznych, projektowania kierunków rozwoju biznesu i gminy. Przedsiębiorcy zarzucają brak przemyślanego planowania długookresowego i wizji rozwoju gminy. W tych sprawach deklarują, że mogliby być partnerami dla gminy, jednak często mają wrażenie przedmiotowego ich traktowania, a ich rola ogranicza się do płacenia podatków i wspierania gminnych uroczystości. Podejście takie ogranicza szanse na uznanie roli publicznej przedsiębiorstw, jak również postrzeganie przedsiębiorców jako świadomych kreatorów zmian społecznych. Niektórzy badani zgłaszali także opinie przeciwne - nie chcą włączać się we współplanowanie przyszłości gminy, uważają, że nie należy łączyć funkcji biznesowych z samorządowymi.

Na podstawie zgromadzonych informacji można stwierdzić, iż w relacjach $z$ urzędem gminy i władzami dominuje tzw. dyskrecjonalna filantropia (Marsden 2000), charakteryzująca się uznaniowym przeznaczaniem środków finansowych na cele dobroczynne i wykonywaniem niektórych prac woluntarystycznych. Ingerowanie w sprawy polityki publicznej nie jest powszechnie akceptowane, co utrudnia firmom dążenie do korporacyjnego obywatelstwa.

W zakresie relacji ze społecznością lokalną opisane przez respondentów relacje można rozpatrywać w co najmniej dwóch wymiarach. Pierwszy dotyczy relacji stałych, utrwalonych wieloletnim doświadczeniem $\mathrm{z}$ organizacjami, drugi 
zaś incydentalnych. Pierwszy sprowadza się głównie do pomocy lokalnym organizacjom pozarządowym tradycyjnie działającym na wsi. W tym wypadku inicjatorami zwykle nie są przedsiębiorcy, lecz przedstawiciele organizacji szukający zewnętrznego wsparcia finansowego i organizacyjnego. Kryterium zaangażowania we współpracę lub pomoc stanowią personalne znajomości oraz podzielanie wspólnych wartości. W zamian przedsiębiorcy uzyskują satysfakcję, uznanie i wdzięczność. W przypadku drugiego wymiaru stroną są niezrzeszeni mieszkańcy lub sąsiedzi firmy. Relacje dotyczą zaś sytuacji konfliktowych, powstających w wyniku oddziaływania firm na otoczenie. W tym przypadku powodem wzajemnego niezrozumienia jest najczęściej sprzeczna wizja rozwoju czy zagospodarowania danego miejsca.

W kształtowaniu relacji wydaje się mieć znaczenie także zakorzenienie stron w lokalnej społeczności (pochodzenie z tej społeczności lub spoza niej). Obcym trudniej uzyskać akceptację działań, miejscowym zaś łatwiej, nawet jeśli ich działanie wpływa niekorzystnie na otoczenie (np. hałas, odór). $Z$ drugiej strony zaś, przedsiębiorcom zakorzenionym i identyfikującym się z miejscową ludnością bardziej zależy na relacjach sąsiedzkich i akceptacji otoczenia.

Relacje ze społecznością charakteryzuje więc, podobnie jak w przypadku kontaktów z urzędem gminy i jej władzami, dyskrecjonalna filantropia i reaktywne zaangażowanie polegające na konieczności podjęcia działania w wyniku nacisku społecznego, w celu rozwiązania problemu wynikającego z oddziaływania firmy na otoczenie.

Badani przedsiębiorcy prezentowali postawę zachowawczą wobec koncepcji społecznej odpowiedzialności. Deklarowana filantropia jest z pewnością dowodem na istnienie, w ich świadomości, poczucia odpowiedzialności wobec lokalnej społeczności. Wydaje się jednak, że ma ona ograniczony (wykluczający) charakter. Nie jest bowiem „służbą nieznanemu potrzebującemu”, wynikającą z potrzeby moralnej czy etycznej, jest to raczej pomoc swojemu znajomemu, czyli upraszczając prawie tak jakby sobie. Na podstawie zgromadzonego materiału badawczego trudno doszukać się znamion poczucia odpowiedzialności wobec środowiska naturalnego i społecznego w szerszym zakresie. Odwołując się do tzw. piramidy społecznej odpowiedzialności biznesu, zaproponowanej przez Archie Carrolla (1991), można stwierdzić, że przedsiębiorcy uczestniczący w badaniu uznawali swoje obowiązki ekonomiczne (zasilanie budżetu), prawne (spełnianie warunków prawnych) czy filantropijne (np. pomoc samorządowi czy organizacjom pozarządowym) wobec wspólnoty gminnej. W ich wypowiedziach jednak zabrakło argumentów o charakterze etycznym. 


\section{Bibliografia}

Altman B. W., Vidaver-Cohen D. (2000). A framework for understanding corporate citizenship, "Business and Society Review", no. 105 (1), s. 1-7.

Atterton J., Affleck A. (2010). Rural businesses in the north east of England: Final survey results 2010. Centre for Rural Economy Research Report (June), http://www.ncl.ac.uk/cre/publish/ researchreports/index.htm [dostęp 20.10.2017].

Bański J. (2015). Uwarunkowania rozwoju przedsiębiorczości na wsi - wybrane zagadnienia, „Roczniki Naukowe Ekonomii Rolnictwa i Rozwoju Obszarów Wiejskich”, nr 102 (1).

Bowen H. R. (1953). Social responsibilities of the businessman. Harper, New York.

Carroll A. B. (1991). The pyramid of corporate social responsibility, "Business Horizons", no. 34 (4) (July-August), s. 39-48.

Carroll A. B. (1999). Corporate social responsibility: Evolution of a definitional construct, "Business \& Society", no. 38 (3), s. 268-295.

Carroll A. B. (2015), Corporate social responsibility. „Organizational Dynamics”, no. 44 (2), s. 87-96.

Carroll A. B., Shabana K. M. (2010). The business case for corporate social responsibility: A review of concepts, research and practice, "International Journal of Management Reviews", no. 12 (1), s. 85-105.

Crane A. (ed.) (2008). The Oxford handbook of corporate social responsibility. Oxford Handbooks.

Davis K. (1960). Can business afford to ignore social responsibilities?, "California Management Review", no. 2, s. 70-76.

Davis K. (1973). The case for and against business Assumption of social responsibilities, "Academy of Management Journal”, no. 16 (2), s. 312-322.

Dziemianowicz W., Mackiewicz M., Malinowska E., Misiąg W., Tomalak M. (2000). Wspieranie przedsiębiorczości przez samorząd terytorialny. Polska Fundacja Promocji i Rozwoju Małych i Średnich Przedsiębiorstw, Warszawa.

Friedman M. (2007). The social responsibility of business is to increase its profits, [w:] W. Ch. Zimmerli, M. Holzinger, K. Richter (eds.), Corporate ethics and corporate governance, s. 173-178. Przedruk artykułu o tym samym tytule $\mathrm{z}$ "The New York Times Magazine" 1970, no. 13 (September).

Gabińska C. G. (2012). Kształcenie na rzecz przedsiębiorczości na obszarach wiejskich, „Przedsiębiorczość - Edukacja", nr 8, s. 259-277.

Griffin J. J. (2000). Corporate Social Performance: Research Directions for the 21st Century, "Business and Society", no. 39 (4), s. 479-493.

Kłodziński M. (1998). Rozwój przedsiębiorczości na obszarach wiejskich, „Wieś i Rolnictwo”, nr 3.

Kłodziński M. (2010). Mikroprzedsiębiorczość na obszarach wiejskich, „Wieś i Rolnictwo”, nr 2 (147), s. 20-34.

Kłodziński M. (2014). Przedsiębiorczość pozarolnicza na wsi w procesie wielofunkcyjnego rozwoju obszarów wiejskich, „Wieś i Rolnictwo”, nr 1 (162), s. 97-112.

Kłodziński M., Dzun W. (2003). Aktywizacja wiejskich obszarów problemowych. Instytut Rozwoju Wsi i Rolnictwa PAN, Warszawa.

Kłodziński M., Fedyszak-Radziejowska B. (red.) (2002). Przedsiębiorczość wiejska w Polsce i krajach Unii Europejskiej. Instytut Rozwoju Wsi i Rolnictwa PAN, Warszawa.

Marsden Ch. (2000). The new corporate citizenship of big business: Part of the solution to sustainability?, "Business and Society Review", no. 105 (1), s. 8-25.

McIntosh M., Leipziger T. R., Coleman G. (2003). Living corporate citizenship. Strategic routes to socially responsible business. London. 
McWilliams A., Siegel D. (2001). Corporate Social Responsibility: A Theory of the Firm Perspective, "Academy of Management Review", no. 26 (1), s. 117-127.

Nurzyńska I. (2011). Rola instytucji w procesie promowania i rozwoju przedsiębiorczości na terenach wiejskich, „Wieś i Rolnictwo”, nr 3 (152), s. 106-126.

Nurzyńska I. (2013). Uwarunkowania instytucjonalne rozwoju przedsiębiorczości na obszarach wiejskich, „Wieś i Rolnictwo”, nr 3, s. 119-137.

Nurzyńska I., Poczta W. (2014). Polska wieś 2014. Raport o stanie wsi. Wydawnictwo Naukowe Scholar, Warszawa.

Ostrowski L. (2000). Przedsiębiorczość pozarolnicza chłopów jako czynnik budowania wielofunkcyjności obszarów wiejskich, [w:] K. Gorlach, A. M. Pyrć (red.), Węłowe kwestie społeczne wsi polskiej u progu XXI wieku. Uniwersytet Jagielloński, Kraków.

Otłowska A., Buks J., Chmieliński P. (2006). Przedsiębiorczość na obszarach wiejskich - stan i perspektywy rozwoju. Instytut Ekonomiki Rolnictwa i Gospodarki Żywnościowej, Państwowy Instytut Badawczy.

Porter M. E. (1992). Strategia konkurencji. Metody analizy sektorów i konkurencji. Państwowe Wydawnictwo Ekonomiczne, Warszawa.

Rosner A., Stanny M. (2014). Monitoring rozwoju obszarów wiejskich. Etap I. Przestrzenne zróżnicowanie poziomu rozwoju społeczno-gospodarczego obszarów wiejskich w 2010 roku. Fundacja Europejski Fundusz Rozwoju Wsi Polskiej, Instytut Rozwoju Wsi i Rolnictwa PAN, Warszawa.

Schwartz M., Carroll A. B. (2003). Corporate social responsibility: A three-domain approach, "Business Ethics Quarterly", no. 13 (4), s. 503-530.

Waddock S. A., Graves S. B. (1997). The Corporate Social Performance-Financial Performance Link, "Strategic Management Journal", no. 18 (4), s. 303-320.

Wilkin J., Nurzyńska I. (2016). Polska wieś 2016. Raport o stanie wsi. Wydawnictwo Naukowe Scholar, Warszawa.

Windsor D. (2001). The future of corporate social responsibility, "The International Journal of Organizational Analysis", no. 9 (3), s. 225-256.

\section{Małgorzata Marks-Krzyszkowska}

\section{RELATIONS OF BUSINESS WITH THE RURAL ENVIRONMENT}

Abstract. The aim of the article is to present the opinions of entrepreneurs on their relationship with local authorities and the local community. The considerations were based on the results of qualitative field studies conducted in 2016 using a technique of individual in-depth interviews with seven representatives of companies operating in rural areas. Analyses, embedded in the concept of corporate social responsibility, lead to the conclusion that in business relations with the commune authorities (similarly to non-governmental organizations and the local community) the so-called discretionary philanthropy and reactive involvement. They resulted mainly from social pressure, not the needs of entrepreneurs. Entrepreneurs referred to the sense of social responsibility towards the local community in economic, legal and philanthropic scope. There were no ethical arguments.

Key words: corporate social responsibility, enterprises in the countryside, relations with the local environment, rural areas. 